\section{Diet quality among adolescents has deteriorated: a panel study in Niterói, Rio de Janeiro State, Brazil, 2003-2008}

\author{
A queda na qualidade da alimentação dos adolescentes \\ brasileiros: um estudo de painel em Niterói, \\ Estado do Rio de Janeiro, Brasil, 2003-2008 \\ La caída en la calidad de la alimentación de los \\ adolescentes brasileños: un estudio de panel \\ en Niterói, Estado de Río de Janeiro, \\ Brasil, 2003-2008
}

Luana Silva Monteiro ${ }^{1}$

Paulo Rogerio Melo Rodrigues 2

Gloria Valeria da Veiga 1

Dirce Maria Lobo Marchioni 3

Rosangela Alves Pereira 1

doi: $10.1590 / 0102-311 \times 00124715$

\begin{abstract}
This study aimed to analyze changes in the diet quality of adolescents from public schools in Niterói, Rio de Janeiro State, Brazil, over a five-year period. Data on the food consumption of adolescents (12-19 years) were obtained by means of two sets of 3-day food records in two school-based, cross-sectional studies conducted in 2003 and 2008. The Brazilian Revised Healthy Eating Index (BHEI-R) was used to estimate dietary quality. From 2003 to 2008 there was an overall decrease in the scores attributed to "total vegetables", "dark green and orange vegetables", and "meat, eggs, and legumes", but there was an increase in the score for "milk and dairy" (4.0 vs. 5.2; $p<0.01$ ). Among female adolescents, the BHEI-R decreased (64.1 vs. 62.4; $p=0.04$ ), as did the scores attributed to "total vegetables", "dark green and orange vegetables", "meat, eggs, and legumes", and "solid fat, alcohol, and added sugar". In contrast, among males, only the "whole grains" score decreased (0.2 vs. 0.1; $p=0.04$ ). From 2003 to 2008, the diet quality of female public school students declined in Niterói.
\end{abstract}

Diet Surveys; Food Consumption; Adolescent

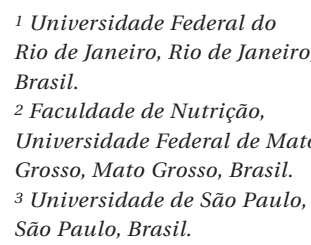

1 Universidade Federal do Rio de Janeiro, Rio de Janeiro, Brasil.

2 Faculdade de Nutrição, Universidade Federal de Mato Grosso, Mato Grosso, Brasil. 3 Universidade de São Paulo, São Paulo, Brasil.

\author{
Correspondence \\ L. S. Monteiro \\ Rua Anália Franco 275, \\ Rio de Janeiro, $R J$ \\ 21330-120, Brasil. \\ luananutrir@gmail.com
}




\section{Introduction}

During adolescence (10 to 19 years), adequate diet is important for proper growth and development. Thus, monitoring adolescents' food intake is crucial for supporting interventions to promote healthy dietary habits in this age group.

According to the 2008-2009 Brazilian Dietary Survey, adolescents showed worse eating habits than adults and the elderly ${ }^{1}$. Adolescents' dietary intake has also been marked by high energydense items, excessive sugar, fat, and sodium, and low amounts of vegetables, fruits, calcium, and iron 2,3,4. Such food choices can contribute to unbalanced energy intake and inadequate intake of vitamins and minerals, thus promoting excess weight gain and jeopardizing adolescents' health 5,6 .

The usual approach to assess dietary exposure focuses on the evaluation of energy and/or nutrient intake or food and/or food group consumption. However, this approach does not allow the investigation of the combined effect of several dietary components and/or provide a suitable basis for interventions. Thus, approaches that seek to evaluate overall diet are important for supporting intervention development aimed at healthy eating 7 . Such approaches include indices that assess diet quality, such as the Revised Healthy Eating Index (RHEI) proposed by Guenther et al. 8 . The diet quality indices evaluate how closely a diet approaches a theoretical "eating pattern" defined on the basis of food guidelines and dietary recommendations 9 .

Guenther et al. 8, based on 2005 Dietary Guidelines for the American Population 10, developed the RHEI, emphasizing whole grains, vegetables, beneficial fats, and energy from solid fats, alcohol, and added sugar. Based on the American RHEI 8 and the Brazilian Dietary Guidelines 11 , Previdelli et al. 12 proposed the Brazilian Revised Healthy Eating Index (BHEI-R), aimed at characterizing both healthy and harmful aspects of the diet; additionally, Andrade et al. 13 evaluated the validity and reliability of this index, concluding that it is reliable and structurally valid to monitor diet quality in Brazil. The BHEI-R has been used to summarize diet quality, highlighting key dietary characteristics, and is considered a useful tool in nutritional epidemiology 14 .

Previous studies have reported the decline in adolescents' diet quality 5,15. Despite the topic's relevance, there are few studies in Brazil on trends in food consumption during adolescence. The present study used the BHEI-R 12 to analyze changes in adolescents' diet from 2003 to 2008.

\section{Materials and methods}

This study is a secondary analysis of two crosssectional school-based studies in the city of Niterói, Rio de Janeiro State, Brazil, in 2003 and 2008, which examined adolescents 12 to 19 years of age enrolled in public schools, with the primary objective of assessing biochemical markers of cardiovascular diseases.

The two studies adopted the same sample design to ensure comparability. Selection of participants was based on a cluster sample design (with one selection stage), and the original sample size was calculated assuming $25 \%$ prevalence of hypercholesterolemia (the most common alteration in blood lipids in adolescents 16 ), 95\% confidence interval (95\%CI), and 5\% maximum error. Estimated sample size was 600 students, and allowing for predicted losses of $30 \%$, the final sample size was set at 780 adolescents 17 . The probability of selecting classes from each school was proportional to the total number of students in each age group in each school; as a result, in 2003, 28 classes were selected, and in 200830 classes were selected among the 33 public schools chosen for the studies. Pregnant adolescents and those with physical disabilities that prevented anthropometric assessment were excluded from the study.

The two studies were approved by the respective Institutional Review Boards of the Clementino Fraga Filho University Hospital (2003) and the Martagão Gesteira Institute of Pediatrics and Childcare (2008), both belonging to the Federal University of Rio de Janeiro (UFRJ). Only adolescents who provided an informed consent form signed by a parent or guardian or by the adolescents themselves (when they were 18 or older) were allowed to participate in the study.

A digital scale was used to measure weight, with participants barefoot and wearing light clothing. Height was measured with a portable stadiometer, following the recommendations of Gordon et al. 18. Body mass index (BMI = weight/ height2) by age and sex was used to classify weight status according to World Health Organization guidelines 19 , and adolescents with z-score $>+1$ were considered overweight.

\section{Dietary assessment and analysis}

In both studies, adolescents completed a set of 3-day dietary records (two weekdays and one weekend day), after being instructed to describe all foods and beverages (except water) consumed on the specified days, plus time and place of meals. After they completed the records, a nutritionist reviewed the food records with the partici- 
pant to clarify or complete data as needed. Energy and nutrient intakes were estimated using the NutWin software (Escola Paulista de Medicina, Universidade Federal de São Paulo, São Paulo, Brazil), based on the U.S. Department of Agriculture food composition table. For foods not in that database, food composition was obtained from the Brazilian Food Composition Table 20.

\section{Brazilian Revised Healthy Eating Index (BHEI-R)}

To estimate BHEI-R, foods were grouped according to the BHEI-R food groupings. Mixed dishes including more than one food group (e.g., sandwiches, pizzas, stuffed pasta, chocolate milk, and other mixtures) were broken down into their ingredients, classified in the appropriate groups.

BHEI-R is estimated by adding all points attributed to 12 components characterizing different aspects of the diet. Nine of these components are based on food groups: "total grains" (all grains, whether whole or not); "whole grains" (only whole grains); "total fruit" (all fruits and fruit juices); "whole fruit" (only fruits in pieces, excluding fruit juices); "total vegetables" (all vegetables and legumes); "dark green and orange vegetables and legumes"; "milk and dairy"; "meat, eggs, and beans"; and "oils" (sources of mono- and polyunsaturated fatty acids and omega-3). Two components are related to nutrients ("sodium" and "saturated fat"), and the last component consists of calories from "solid fat, alcohol, and added sugar" (SoFAAS), which include foods providing solid fats (for example, butter, lard, and hydrogenated vegetable fats), alcoholic beverages, and added sugar (including table sugar, soft drinks, jams, jelly, and other processed foods) (Table 1).

BHEI-R was calculated with the procedures proposed by Guenther et al. ${ }^{8}$. Initially, the energy (kcal) provided by each food group in the 3-day dietary records was estimated. Then the energy density of each analyzed food group per 1,000kcal was calculated (Equation 1).

\begin{tabular}{|c|c|}
\hline \multirow{2}{*}{$\begin{array}{l}\text { Energy density } \\
\text { form the food } \\
\text { group in } 1,000 \mathrm{kcal}\end{array}=$} & $\begin{array}{l}\text { total energy provided by the food group } \\
\text { in three days of food records (kcal) } * 1,000\end{array}$ \\
\hline & \\
\hline
\end{tabular}

For components based on nutrients (sodium, saturated fat) the density of nutrients per $1,000 \mathrm{kcal}$ was estimated, according to Equation 2:

$$
\begin{aligned}
& \text { Nutrient density } \\
& \text { in } 1,000 \mathrm{kcal}
\end{aligned}=\frac{\begin{array}{c}
\text { total nutrient intake in three days } \\
\text { of food records } * 1,000
\end{array}}{\begin{array}{c}
\text { total energy intake in three days } \\
\text { of food records }(\mathrm{kcal})
\end{array}}
$$

As shown in Table 1, the score assigned to each component of BHEI-R was defined according to the number of servings or nutrient amount consumed per $1,000 \mathrm{kcal}$. To estimate the number of servings consumed in each food group, the mean energy content food group portion defined by the Brazilian Ministry of Health was taken as the reference 12 (Table 1). The cutoff points for maximum, intermediate, and minimum scores of BHEI-R components were based on the Brazilian Dietary Guidelines 11 and internationally accepted dietary recommendations for saturated fat and sodium intake, plus information on SoFAAS intake from a population-based study (Table 1) 8,21,22,23. A detailed description of the criteria for minimum, intermediate, and maximum scores of each component can be found in Previdelli et al. 12.

\section{Data analysis}

The Kolmogorov-Smirnov test was applied to verify the symmetry of distributions of continuous variables. The Student t-test and Mann-Whitney test were used to assess continuous variable variations in the five-year period from 2003 to 2008. Means and 95\%CI of the BHEI-R and component scores were calculated. In addition, the proportion of adolescents who had the minimum and maximum scores for each component was estimated. The contribution of all SoFAAS foods and soft drinks, solid fats, and added sugar to total energy intake was estimated. All analyses were stratified according to sex, age group $(<15 / \geq 15$ years old), and weight status (non-overweight / overweight). Tests with $\mathrm{p}$-values $<0.05$ were considered statistically significant.

Data were analyzed using the IBM SPSS, version 21 (IBM Corp., Armonk, U.S.A).

\section{Results}

In 2003, 764 adolescents were considered eligible for the study, 610 (80\%) were examined, and 433 (71\% of examined) completed 3-day food records. In 2008, 918 adolescents were eligible for the study, 700 (76\%) were examined, and 510 (73\% of examined) completed 3-day food records.

Male adolescents totaled $31 \%$ of the sample in 2003 and $36 \%$ in 2008 ( $p=0.1$ ). There was no difference in the mean age of adolescents between the two years (2003: 16.9 years, $\mathrm{SD}=1.5$; 2008: 16.1 years, $S D=1.8$ ). The proportion of overweight adolescents was $16.9 \%$ in 2003 and $22 \%$ in 2008 ( $\mathrm{p}=0.06)$.

From 2003 to 2008, mean BHEI-R score decreased from $64.4(\mathrm{SD}=10.0)$ to $63.1(\mathrm{SD}=10.9)$ 
Table 1

Components and scoring criteria in the Brazilian Revised Healthy Eating Index (BHEI-R).

\begin{tabular}{|c|c|c|c|c|}
\hline $\begin{array}{l}\text { Components based on } \\
\text { food groups * }\end{array}$ & Criteria for maximum score & $\begin{array}{l}\text { Maximum } \\
\text { score (points) }\end{array}$ & Intermediate score & $\begin{array}{l}\text { Minimum score } \\
\text { (zero points) }\end{array}$ \\
\hline Total grains & 2.0 servings $1,000 \mathrm{kcal}$ & 5 & Apportioned according to consumption & No consumption \\
\hline Whole grains & 1.0 servings $/ 1,000 \mathrm{kcal}$ & 5 & & \\
\hline Meat, egg \& beans & 1.0 servings $/ 1,000 \mathrm{kcal}$ & 10 & & \\
\hline Total fruit & 1.0 servings $/ 1,000 \mathrm{kcal}$ & 5 & & \\
\hline Whole fruit & 0.5 servings $/ 1,000 \mathrm{kcal}$ & 5 & & \\
\hline Total vegetables & 1.0 servings $/ 1,000 \mathrm{kcal}$ & 5 & & \\
\hline $\begin{array}{l}\text { Dark green and orange } \\
\text { vegetables \& legumes }\end{array}$ & 0.5 servings $/ 1,000 \mathrm{kcal}$ & 5 & & \\
\hline Milk \& dairy & 1.5 servings $/ 1,000 \mathrm{kcal}$ & 10 & & \\
\hline Oils ** & 0.5 servings $/ 1,000 \mathrm{kcal}$ & 10 & & \\
\hline \multicolumn{5}{|l|}{$\begin{array}{l}\text { Components based on } \\
\text { nutrients }\end{array}$} \\
\hline Saturated fat & $\begin{array}{c}\leq 7 \% \text { TEl (according to } \\
\text { the Brazilian Society } \\
\text { of Cardiology) }\end{array}$ & 10 & $\begin{array}{c}8 \text { points: }>7 \text { and }<10 \% \text { do TEI (according } \\
\text { to WHO guidelines) } \\
\text { Between } 10 \text { and } 15 \% \text { of } \mathrm{TEI} \text {, the points are } \\
\text { calculated proportionally }\end{array}$ & $\geq 15 \%$ of $\mathrm{TEI} * \star \star$ \\
\hline Sodium & $\begin{array}{c}\leq 750 \mathrm{mg} / 1,000 \mathrm{kcal} \\
\text { (adequate intake - Dietary } \\
\text { Reference Intake) }\end{array}$ & 10 & $\begin{array}{l}8 \text { points: } 1,000 \mathrm{mg} / 1,000 \mathrm{kcal} \text { * } \\
\text { Between } 1,000 \mathrm{mg} \text { and } 2,000 \mathrm{mg} / 1,000 \mathrm{kcal} \\
\text { the points are calculated proportionally }\end{array}$ & $\geq 2,000 \mathrm{mg} / 1,000 \mathrm{kcal} \#$ \\
\hline $\begin{array}{l}\text { Energy supplied by food } \\
\text { sources of SoFAAS }\end{array}$ & $\leq 10 \%$ TEl \#\# & 20 & $\begin{array}{l}\text { Apportioned according to consumption } \\
\qquad>10 \% \text { and }<35 \% \text { do TEl }\end{array}$ & $\geq 35 \%$ \#\#\# of TEI \\
\hline
\end{tabular}

SoFAAS: solid fat (saturated e trans), alcohol, and added sugar; TEl: total energy intake; WHO: World Health Organization.

* Score based on Brazilian Dietary Guidelines 11;

** Oils: sources of mono and polyunsaturated fatty acids and omega-3;

*** This limit corresponds to the 85th percentile of saturated fat intake distribution observed in the 2003 São Paulo Food and Health Survey (ISA-Capital 2003) 42;

\# This limit is the twice the recommendation from the Brazilian Dietary Guidelines ${ }^{11}$;

\#\# This limit corresponds to the 16th percentile of energy supplied by food sources of solid fat (saturated and trans), alcohol, and added sugar intake distribution observed in the 2003 São Paulo Food and Health Survey (ISA-Capital 2003) 42;

\#\#\# This limit corresponds to the 85th percentile of energy supplied by food sources of solid fat (saturated e trans), alcohol, and added sugar intake distribution observed in the 2003 São Paulo Food and Health Survey (ISA-Capital 2003) 42.

( $p=0.04$ ), due mainly to a drop in the consumption of "total vegetables", "dark green and orange vegetables and legumes", and "meat, eggs, and beans" and an increase in the intake of SoFAAS foods. Nevertheless, there was an increase in the mean score attributed to the "milk and dairy" group, from 4.0 to 5.2 points ( $\mathrm{p}<0.01$ ) (Table 2 ).

In $2003,38 \%$ of adolescents did not consume any portions of "whole fruit" (obtaining zero points for this component) and $76 \%$ reported no consumption of "whole grains"; in 2008, these proportions did not change significantly $(42 \%$ and $78 \%$, respectively) (Table 3 ).

There was also a significant increase in the number of adolescents who reported not consuming "dark green and orange vegetables and legumes" ( $14 \%$ vs. $27 \%$; p < 0.05$)$ or "total fruit"
( $18 \%$ vs. $25 \%$; $p<0.05)$ in the target period. However, the proportion of adolescents consuming at least three daily portions of "milk and dairy" rose from $5 \%$ in 2003 to $11 \%$ in 2008 (p < 0.01 ) (Table 3).

Across the two studies, there was no variation in the "sodium" score (mean 4.7 in both studies) (Table 2), although this mean represents less than $50 \%$ of the maximum score (10 points), indicating high sodium intake. Mean sodium intake was 2,911 mg/day in 2003 and 3,355mg/day in 2008 (p $\leq 0.01$ ); these means are higher than the tolerable upper intake level $(2,300 \mathrm{mg})$ recommended by the U.S. Institute of Medicine ${ }^{22}$. In both studies, less than $1 \%$ of adolescents reported sodium intake below $750 \mathrm{mg} / 1,000 \mathrm{kcal}$, defined as the limit for adequate intake according to the U.S. Insti- 


\begin{tabular}{|c|c|c|c|c|c|c|}
\hline \multirow[t]{2}{*}{ BHEI-R and components } & \multirow{2}{*}{$\begin{array}{l}\text { Maximum } \\
\text { score }\end{array}$} & \multicolumn{2}{|c|}{2003} & \multicolumn{2}{|c|}{2008} & \multirow[t]{2}{*}{ p-value* } \\
\hline & & Mean & $95 \% \mathrm{Cl}$ & Mean & $95 \% \mathrm{Cl}$ & \\
\hline BHEI-R & 100 & 64.4 & $63.4-65.3$ & 63.1 & 62.1-64.0 & 0.04 \\
\hline Total fruit & 5 & 1.7 & $1.6-1.9$ & 1.7 & $1.5-1.8$ & 0.38 \\
\hline Whole fruit & 5 & 1.6 & $1.4-1.8$ & 1.6 & $1.5-1.8$ & 0.85 \\
\hline Total vegetables & 5 & 3.6 & 3.4-3.7 & 3.4 & $3.2-3.5$ & 0.04 \\
\hline $\begin{array}{l}\text { Dark green and orange vegetables \& } \\
\text { legumes }\end{array}$ & 5 & 3.0 & 2.9-3.3 & 2.7 & $2.5-2.9$ & $<0.01$ \\
\hline Total grains & 5 & 4.9 & $4.9-5.0$ & 4.9 & $4.9-5.0$ & 0.66 \\
\hline Whole grains & 5 & 0.2 & $0.2-0.3$ & 0.2 & $0.1-0.2$ & 0.28 \\
\hline Meat, egg \& beans & 10 & 8.8 & $8.6-8.9$ & 8.5 & $8.4-8.7$ & 0.04 \\
\hline Milk \& dairy & 10 & 4.0 & $3.7-4.3$ & 5.2 & 4.9-5.4 & $<0.01$ \\
\hline Oils ** & 10 & 7.4 & $7.2-7.7$ & 7.2 & $7.0-7.5$ & 0.28 \\
\hline Saturated fat & 10 & 8.0 & $7.8-8.2$ & 8.2 & $8.1-8.4$ & 0.52 \\
\hline Sodium & 10 & 4.7 & $4.5-5.0$ & 4.7 & 4.4-4.9 & 0.84 \\
\hline SoFAAS & 20 & 16.1 & $15.6-16.6$ & 14.4 & 13.9-15.1 & $<0.01$ \\
\hline
\end{tabular}

SoFAAS: solid fat (saturated e trans), alcohol, and added sugar.

* Mann-Whitney test;

** Oils: sources of mono and polyunsaturated fatty acids and omega-3.

tute of Medicine 22 and related to the maximum score for this BHEI-R component (Table 3).

Female adolescents' total BHEI-R score decreased from 2003 to 2008 (64.1 vs. 62.4; $\mathrm{p}=0.04$ ), as did their score for "total vegetables" (3.5 vs. 3.2; $\mathrm{p}=0.02$ ), "dark green and orange vegetables and legumes" (3.0 vs. $2.5 ; \mathrm{p}<0.01$ ), "meat, eggs, and beans" (8.7 vs. $8.4 ; \mathrm{p}<0.01)$, and SoFAAS (16.3 vs. $14.5 ; \mathrm{p}<0.01)$. In contrast, males only showed a significant reduction in "whole grains" ( $0.2 \mathrm{vs.}$ $0.1 ; \mathrm{p}=0.04)$, while the "milk and dairy" score increased in both sexes ( $\mathrm{p}<0.01)$ (females: 3.9 vs. 5.2; males: 4.2 vs. 5.1) (Table 4).

There was an increase in the contribution of SoFAAS foods to total energy intake in the study period, from $22 \%$ to $26 \%$ ( $p<0.01$ ). Increased soft drink consumption appears to be the main factor responsible for this change, as the contribution of such beverages to total energy intake increased from 15\% in 2003 to 19\% in 2008 (data not shown).

In both 2003 and 2008, there were no significant differences in overall BHEI-R and components according to adolescents' weight status (non-overweight vs. overweight) and age group ( $<15$ years old vs. $\geq 15$ years old) (data not shown).

\section{Discussion}

The present study analyzed dietary data obtained in two cross-sectional school-based studies aiming to assess changes in the diet of adolescents from public schools in Niterói, from 2003 to 2008. This period saw a decrease in adolescents' diet quality as revealed by reduced mean BHEI$\mathrm{R}$ score, which was due to decreased scores for the consumption of vegetables, legumes, meat, and eggs. There was also an increase in the consumption of SoFAAS foods, especially soft drinks. Sodium intake remained above the recommended level, and the consumption of fruits, whole grains, and milk and dairy products remained below the recommendations in both studies.

Other studies have also shown low consumption of fruits and vegetables and high intake of soft drinks and sweet and savory snacks among adolescents 1,24. However, in Brazil, only Wendpap et al. 25 had previously used the BHEI-R to evaluate the diet quality of 1,326 10-14 year-old adolescents from Cuiabá, Mato Grosso State, which presented a mean BHEI-R of 75.1 points. The difference in the BHEI-R between adolescents in Niterói and Cuiabá can be explained by the use of a food frequency questionnaire to obtain data on food consumption in Cuiabá. The FFQ has been associated with measurement er- 
Table 3

Proportion (\%) of adolescents from public schools in Niterói, Rio de Janeiro State, Brazil, with minimum (zero) and maximum score on the Brazilian Revised Healthy Eating Index (BHEl-R) components, 2003 ( $N=433$ ) and 2008 ( $N=510$ ).

\begin{tabular}{lcccc}
\hline BHEI-R and components & \multicolumn{2}{c}{ Minimum score (\%) } & \multicolumn{2}{c}{ Maximum score (\%) } \\
& $\mathbf{2 0 0 3}$ & $\mathbf{2 0 0 8}$ & $\mathbf{2 0 0 3}$ & $\mathbf{2 0 0 8}$ \\
\hline Total fruit & $17.8^{*}$ & $24.5^{*}$ & 8.8 & 9.8 \\
Whole fruit & 38.1 & 41.7 & 13.9 & 15.3 \\
Total vegetables & 0.2 & 0.2 & 50.6 & 45.9 \\
Dark green and orange vegetables \& legumes & $14.3 *$ & $27.2^{*}$ & 50.6 & 47.3 \\
Total grains & 0.0 & 0.0 & 93.5 & 92.7 \\
Whole grains & 75.8 & 77.5 & 0.2 & 0.2 \\
Meat, egg \& beans & 0.0 & 0.0 & 52.2 & 46.5 \\
Milk \& dairy & $2.3 *$ & $0.6 *$ & $5.1 *$ & 10.6 * \\
Oils ** & 0.5 & 0.0 & 39.3 & 36.5 \\
Saturated fat & 1.2 & 0.8 & 20.3 & 15.7 \\
Sodium & 11.1 & 13.9 & 0.9 & 0.6 \\
SoFAAS & 5.5 & 9.2 & 35.3 & 34.1 \\
\hline
\end{tabular}

SoFAAS: solid fat (saturated e trans), alcohol, and added sugar.

* Comparison of 2003 and 2008: $p<0.05$.

** Oils: sources of mono and polyunsaturated fatty acids and omega-3.

Table 4

Means and $95 \%$ confidence intervals $(95 \% \mathrm{Cl}$ ) for the Brazilian Revised Healthy Eating Index (BHEI-R) components, by gender, in adolescents enrolled in public schools in Niterói, Rio de Janeiro State, Brazil, 2003 ( $N=433)$ and 2008 ( $N=510)$.

\begin{tabular}{|c|c|c|c|c|c|c|c|c|c|c|}
\hline \multirow[t]{3}{*}{ BHEI-R and components } & \multicolumn{5}{|c|}{ Girls } & \multicolumn{5}{|c|}{ Boys } \\
\hline & \multicolumn{2}{|r|}{2003} & \multicolumn{2}{|c|}{2008} & \multirow[t]{2}{*}{ p-value * } & \multicolumn{2}{|c|}{2003} & \multicolumn{2}{|c|}{2008} & \multirow[t]{2}{*}{ p-value * } \\
\hline & Mean & $95 \% \mathrm{Cl}$ & Mean & $95 \% \mathrm{Cl}$ & & Mean & $95 \% \mathrm{Cl}$ & Mean & $95 \% \mathrm{Cl}$ & \\
\hline BHEI-R & 64.1 & $63.0-65.3$ & 62.4 & $61.2-63.6$ & 0.04 & 64.9 & $63.2-66.6$ & 64.2 & $62.6-65.8$ & 0.38 \\
\hline Total fruit & 1.7 & $1.5-1.9$ & 1.7 & $1.5-1.9$ & 0.48 & 1.7 & $1.4-2.0$ & 1.7 & $1.4-1.9$ & 0.71 \\
\hline Whole fruit & 1.7 & $1.4-1.9$ & 1.7 & $1.4-1.8$ & 0.53 & 1.5 & $1.2-1.9$ & 1.7 & $1.4-1.9$ & 0.56 \\
\hline Total vegetables & 3.5 & 3.3-3.7 & 3.2 & $3.0-3.4$ & 0.02 & 3.7 & $3.5-4.0$ & 3.7 & 3.4-3.9 & 0.65 \\
\hline Dark green and orange vegetables \& legumes & 3.0 & $2.7-3.2$ & 2.5 & $2.3-2.8$ & $<0.01$ & 3.2 & $2.8-3.5$ & 3.1 & $2.7-3.4$ & 0.57 \\
\hline Total grains & 4.9 & $4.9-5.0$ & 4.9 & $4.9-5.0$ & 0.41 & 4.9 & $4.9-5.0$ & 4.9 & $4.9-5.0$ & 0.71 \\
\hline Whole grains & 0.2 & $0.1-0.3$ & 0.2 & $0.1-0.2$ & 0.97 & 0.2 & $0.1-0.3$ & 0.1 & $0.1-0.2$ & 0.04 \\
\hline Meat, egg \& beans & 8.7 & $8.6-8.9$ & 8.4 & $8.1-8.6$ & $<0.01$ & 8.8 & $8.6-9.1$ & 8.9 & $8.6-9.1$ & 0.95 \\
\hline Milk \& dairy & 3.9 & $3.6-4.3$ & 5.2 & $4.9-5.5$ & $<0.01$ & 4.2 & $3.7-4.6$ & 5.1 & $4.7-5.5$ & $<0.01$ \\
\hline Oils ** & 7.2 & $6.9-7.5$ & 7.0 & $6.7-7.3$ & 0.41 & 7.9 & $7.4-8.3$ & 7.6 & 7.2-7.9 & 0.31 \\
\hline Saturated fat & 7.8 & $7.5-8.0$ & 8.2 & 7.9-8.4 & 0.29 & 8.4 & $8.1-8.7$ & 8.4 & $8.1-8.6$ & 0.57 \\
\hline Sodium & 4.9 & $4.6-5.2$ & 4.7 & $4.4-5.0$ & 0.75 & 4.4 & $4.0-4.9$ & 4.5 & $4.1-4.9$ & 0.74 \\
\hline SoFAAS & 16.3 & $15.7-16.8$ & 14.5 & $13.8-15.2$ & $<0.01$ & 15.6 & $14.5-16.7$ & 14.4 & $13.4-15.4$ & 0.32 \\
\hline
\end{tabular}

SoFAAS: solid fat (saturated e trans), alcohol, and added sugar.

* Mann-Whitney test;

** Oils: sources of mono and polyunsaturated fatty acids and omega-3.

Note: girls vs. boys: 2003 (oils; saturated fat: $p<0.05$ ); 2008 (total vegetables; dark green and orange vegetables and legumes; meat, egg and beans; oils: $p<0.05$ ) 
rors, especially over-reporting of healthy foods like fruits and vegetables 26,27.

Freedman et al. 28 applied the Healthy Eating Index 2005 to analyze food intake among Americans two years or older and estimated a mean score of 1.0 for the "whole grains" group. Although this score was low, it was still five times higher than in adolescents (0.2). Moreover, in this study, the mean SoFAAS score was double that observed in the United States (8.4 points). Krebs-Smith et al. 29 also used the Healthy Eating Index 2005 to investigate whether food intake in the American population agreed with dietary guidelines between 1970 and 2007. The authors reported that SoFAAS sources were being provided in harmful amounts, and that the "total fruit", "total vegetables", "whole fruit", and "milk and dairy" components were below the recommended limits. Nevertheless, it should be pointed out that there are important methodological differences between these studies and the present analysis, particularly the target age group and the dietary assessment tool applied to assess food consumption.

Nielsen \& Popkin 30 also observed variations in soda consumption, reporting that the contribution of sodas to total energy intake increased from $3 \%$ to $6.9 \%$ from 1977 to 2001 in American children and adolescents 2 to 18 years old. Data on household food acquisition obtained in the 2008-2009 Brazilian National Household Budget Survey also showed that household acquisition of soda increased from 19L/per capita/per year in 2002-2003 to $21 \mathrm{~L} /$ per capita/per year in 2008-2009 31 .

The low score for the "sodium" component in this study could be related to adolescents' food habits, with high intake of processed, sodiumrich foods such as crackers, savory snacks, sodas, and preserved meats ${ }^{32}$. He et al. 33 reported an association between soda consumption and increased sodium intake in this age group. Guidelines to restrict sodium intake are among the most important measures for primary prevention of cardiovascular disease 34 .

Regarding the "meat, eggs, and legumes" component, none of the adolescents reached a minimum score. Similar results were observed by Krebs-Smith et al. 29 , who found that Americans consumed meat and legumes in adequate amounts between 1970 and 2007. There was no deficit in protein intake among the adolescents in this study, and meat consumption was likely elevated.

In this study, female adolescents were more predisposed to diminish their diet quality than males. Rojas 35 also indicated that Costa Rican female adolescents had more frequent out-of- home consumption of candies and cookies and higher inadequacy of fruit and vegetable intake than their male counterparts.

There were no differences in BHEI-R scores between overweight and non-overweight adolescents. Hassapidou et al. 36 found that adolescents who were and were not overweight had similar eating habits. This similarity could result from the underreporting of food intake among overweight adolescents because they tend to omit reporting foods that are considered "unhealthy" 37. This could also be associated with reverse causality, because overweight adolescents may restrict their intake to reduce weight gain. This is an inherent limitation to the cross-sectional study design in which exposure and outcome are observed simultaneously.

This study has some limitations. For example, the BHEI-R does not take total daily energy intake into account. Although the scores are estimated according to components' energy density, there is no information on energy intake adequacy, which would be important to prevent an energyunbalanced diet. Nevertheless, the BHEI-R was adapted 12 and validated 13 in Brazil to monitor dietary quality of $\geq 12$ year-old individuals.

The dietary record used to obtain data on dietary intake is associated with the changing usual food consumption; in this study, to reduce measurement error in dietary assessment and to ensure data quality, participants were encouraged to maintain their eating habits and were thoroughly instructed to record foods and beverages consumed. Additionally, during a face-to-face interview, a nutritionist revised the food records to clarify and correct any unclear item. Meanwhile, the food record has strengths; for example, it is not dependent on memory and is considered accurate for obtaining information on the amounts consumed 38 .

Another possible limitation to this study is the loss in sample size. However, there were no significant differences in the distribution according to sex, age, and weight status when comparing the total 2003 and 2008 samples with the analyzed samples (data not shown). In addition, a sample size of 392 adolescents would be sufficient to detect 2-point differences in the BHEI-R means, with a standard deviation of 10 , power of $80 \%$, and $5 \%$ confidence level in a two-tailed test 39 .

This was the first study to analyze time trends in diet quality among adolescents from public schools in Brazil, which was accomplished by comparing adolescents' food intake data obtained in two cross-sectional studies that used the same sample design, targeted the same schools, adopted identical data collection methods, and 
thus guaranteed the two studies' comparability. Investigating a public school-based probabilistic sample emphasizes study representativeness in the study area, especially considering that in Brazil, public schools are one of the few institutions that reach the great majority of low-income children and adolescents, thus being a privileged location for research and intervention.

The study's findings support the idea of a nutritional transition in Brazil in recent decades and may represent changes in adolescent diet during a period of major changes in the country's social and economic scenario, marked by economic growth, improved income redistribution, and increased purchasing power among poorer classes 40,41 . The results of the current study indicate that interventions for adolescents should focus on promoting fresh foods and discouraging consumption of ultra-processed food products, especially those with high added sugar and solid fats.

\section{Contributors}

L. S. Monteiro participated in the data collection in the 2008 survey, data entry and analysis, interpretation of the results, and writing of the manuscript. P. R. M. Rodrigues and D. M. L. Marchioni contributed to the analysis and interpretation of results and revision of the text. G. V. Veiga coordinated the research and collaborated in the interpretation of results and revision of the text. R. A. Pereira conceived the manuscript and participated in the data analysis and interpretation and drafting and final revision of the manuscript.

\section{Conclusion}

This study showed that adolescents from public schools in Niterói, particularly girls, have been choosing processed foods over fresh foods; consequently their diet quality has declined in a five-year span. It also revealed an increase in the consumption of unhealthy foods such as sources of saturated fats, trans-fatty acids, added sugar, and sodium, and a decrease in healthy foods like vegetables, fruits, legumes, and whole grains. In short, this study suggests that the diet quality of adolescents from public schools in Niterói, particularly girls, appears to be deteriorating. These issues should be considered in the formulation of recommendations and dietary guidelines targeting adolescents and should be highlighted when assessing their diet quality.

\section{Acknowledgments}

The authors wish to acknowledge the support of the Brazilian National Research Council (CNPq, project 283/02 - 2003 survey), and the Rio de Janeiro State Research Foundation (FAPERJ, project $8.27-2008$ survey). 
1. Souza AM, Pereira RA, Yokoo EM, Levy RB, Sichier R. Alimentos mais consumidos no Brasil: Inquérito Nacional de Alimentação 2008-2009. Rev Saúde Pública 2013; 47 Suppl 1:190S-9S.

2. Toral N, Slater B, Cintra IP, Fisberg M. Comportamento alimentar de adolescentes em relação ao consumo de frutas e verduras. Rev Nutr PUCCAMP 2006; 19:331-40.

3. Neutzling MB, Araujo CLP, Vieira MFA, Hallal PC, Menezes AMB. Frequência de consumo de dietas ricas em gordura e pobres em fibra entre adolescentes. Rev Saúde Pública 2007; 41:336-42.

4. Farias Junior JC, Nahas MV, Barros MVG, Loch MR, Oliveira ESA, De Bem MFL, et al. Comportamentos de risco à saúde em adolescentes no Sul do Brasil: prevalência e fatores associados. Rev Panam Salud Pública 2009; 25:344-52.

5. Levy RB, Castro IRR, Cardoso LO, Tavares LT, Sardinha LMV, Gomes FS, et al. Consumo e comportamento alimentar entre adolescentes brasileiros: Pesquisa Nacional de Saúde do Escolar (PeNSE), 2009. Ciênc Saúde Coletiva 2010; 15 Suppl 2: 3085-97.

6. Veiga GV, Costa RS, Araújo MC, Souza AM, Bezerra IN, Barbosa FS, et al. Inadequação do consumo de nutrientes entre adolescentes brasileiros. Rev Saúde Pública 2013;47 Suppl 1:212S-21S.

7. Hu FB. Dietary pattern analysis: a new direction in nutritional epidemiology. Curr Opin Lipidol 2002; 13:3-9.

8. Guenther PM, Reedy J, Krebs-Smith SM, Reeve BB, Basiotis PP. Development and evaluation of the Healthy Eating Index 2005: technical report. Washington DC: Center for Nutrition Policy and Promotion, U.S. Department of Agriculture; 2007.

9. Kourlaba G, Panagiotakos DB. Dietary quality indices and human health: a review. Maturitas 2009; 62:1-8.

10. U.S. Department of Health and Human Services; U.S. Department of Agriculture. Dietary guidelines for Americans, 2005. 6th Ed. Washington DC: U.S Department of Health and Human Services/U.S Department of Agriculture; 2005.

11. Coordenação-Geral da Política de Alimentação e Nutrição, Secretaria de Atenção à Saúde, Ministério da Saúde. Guia alimentar para a população brasileira: promovendo a alimentação saudável. Brasília: Ministério da Saúde; 2006. (Série A. Normas e Manuais Técnicos).

12. Previdelli AN, Andrade SC, Pires MM, Vívolo SRF Fisberg RM, Marchioni DML. A revised version of the Healthy Eating Index for the Brazilian population. Rev Saúde Pública 2011; 45:794-8.

13. Andrade SC, Previdelli NA, Marchioni DML, Fisberg RM. Avaliação da confiabilidade e validade do Índice de Qualidade da Dieta Revisado. Rev Saúde Pública 2013; 47:675-8.

14. Horta PM, Santos LC. Qualidade da dieta entre mulheres com excesso de peso atendidas em uma Academia da Cidade de Belo Horizonte, Minas Gerais. Cad Saúde Colet (Rio J.) 2015; 23:206-13.

15. Popkin BM. Sugary beverages represent a threat to global health. Trends Endocrinol Metab 2012; 23:591-3.
16. Gerber IRS, Zielinsky P. Fatores de risco de aterosclerose na infância, um estudo epidemiológico. Arq Bras Cardiol 1997; 69:231-6.

17. Alvarez MM, Vieira ACR, Sichieri R, Veiga GV. Prevalence of metabolic syndrome and of its specific components among adolescents from Niterói City, Rio de Janeiro State, Brazil. Arq Bras Endocrinol Metab 2011; 55:164-70.

18. Gordon CC, Chumlea WC, Roche AF. Stature, recumbent length, and weight. In: Lohman TG, Roche AF, Martorell R, editors. Anthropometric standardization reference manual. Champaign: Human Kinetics Books; 1988. p. 3-8.

19. Onis M, Onyango AW, Borghi E, Syyan A, Nishida C, Siekmann J. Development of a WHO growth reference for school-aged children and adolescents. Bull World Health Organ 2007; 85:660-7.

20. Instituto Brasileiro de Geografia e Estatística. Pesquisa de Orçamentos Familiares - POF 2008- 2009. Tabelas de composição nutricional dos alimentos consumidos no Brasil. Rio de Janeiro: Instituto Brasileiro de Geografia e Estatística; 2011.

21. World Health Organization. Global strategy on diet, physical activity and health. Geneva: World Health Organization; 2004.

22. Food and Nutrition Board, Institute of Medicine. Dietary reference intakes for water, potassium, sodium, chloride, and sulfate. Washington DC: The National Academic Press; 2004.

23. Sociedade Brasileira de Cardiologia. IV diretriz brasileira sobre dislipidemias e prevenção da aterosclerose. Departamento de Aterosclerose da Sociedade Brasileira de Cardiologia. Arq Bras Cardiol 2007; 88 Suppl 1:2-19.

24. Malta DC, Andreazzi MAR, Oliveira-Campos M, Andrade SSCA, Sá NNB, Moura L, et al. Tendência dos fatores de risco e proteção de doenças crônicas não transmissíveis em adolescentes, Pesquisa Nacional de Saúde do Escolar (PeNSE 2009 e 2012). Rev Bras Epidemiol 2014; 17 Suppl 1:77-91.

25. Wendpap LL, Ferreira MG, Rodrigues PRM, Pereira RA, Loureiro AS, Gonçalves-Silva RMV. Qualidade da dieta de adolescentes e fatores associados. Cad Saúde Pública 2014; 30:97-106.

26. Shu XO, Yang G, Jin F, Liu D, Kushi L, Wen W, et al. Validity and reproducibility of the food frequency questionnaire used in the Shanghai Women's Health Study. Eur J Clin Nutr 2004; 58:17-23.

27. Liu L, Wang PP, Roebothan B, Ryan A, Tucker CS, Colbourne J, et al. Assessing the validity of a selfadministered food-frequency questionnaire (FFQ) in the adult population of Newfoundland and Labrador, Canada. Nutr J 2013; 12:49.

28. Freedman LS, Guenther PM, Krebs-Smith SM, Dodd KW, Midthune D. A population's distribution of Healthy Eating Index 2005 component scores can be estimated when more than one 24-hour recall is available. J Nutr 2010; 140:1529-34.

29. Krebs-Smith SM, Jill Reedy J, Bosire C. Healthfulness of the U.S. food supply: little improvement despite decades of dietary guidance. Am J Prev Med 2010; 38:472-7.

30. Nielsen SJ, Popkin BM. Changes in beverage intake between 1977 and 2001. Am J Prev Med 2004; 27:205-10. 
31. Instituto Brasileiro de Geografia e Estatística. Pesquisa de Orçamentos Familiares - POF 2008-2009. Aquisição alimentar domiciliar per capita. Rio de Janeiro: Instituto Brasileiro de Geografia e Estatística; 2010.

32. Cohen DA, Sturm R, Scott M, Farley TA, Bluthenthal R. Not enough fruit and vegetables or too many cookies, candies, salty snacks, and soft drinks? Public Health Rep 2010; 125:88-95.

33. He FJ, Marrero NM, MacGregor GA. Salt intake is related to soft drink consumption in children and adolescents: a link to obesity? Hypertension 2008; 51:629-34.

34. Klaus D, Hoyer J, Middeke M. Salt restriction for the prevention of cardiovascular disease. Dtsch $\mathrm{Ar}$ ztebl Int 2010; 107:457-62.

35. Rojas RM. Fruits and vegetables consumption among Costa Rican adolescents. Arch Latinoam Nutr 2001; 51:81-5.

36. Hassapidou M, Fotiadou E, Maglara E, Papadopoulou SK. Energy intake, diet composition, energy expenditure, and body fatness of adolescents in Northern Greece. Obesity (Silver Spring) 2006; 14:855-62.

\section{Resumo}

O estudo teve como objetivo analisar as mudanças na qualidade da dieta de adolescentes matriculados em escolas públicas em Niterói, Estado do Rio de Janeiro, Brasil, ao longo de cinco anos. Os dados sobre consumo alimentar dos adolescentes (12-19 anos de idade) foram obtidos através de dois conjuntos de registros alimentares de três dias em dois estudos transversais de base escolar, em 2003 e 2008. O Índice Brasileiro de Alimentação Saudável (IAS-R) versão revisada, foi utilizado para estimar a qualidade da dieta. Entre 2003 e 2008, houve uma queda geral na pontuação atribuída a "total de verduras e hortaliças", "verduras e hortaliças de cor laranja" e "carne, ovos e legumes", mas houve um aumento no consumo de "leite e laticínios" $(4,0$ vs. 5,2; $p<0,01)$. Entre adolescentes femininas, houve uma queda do IAS-R (64,1 vs. 62,$4 ; p=0,04$ ), assim como, do consumo de "total de verduras e hortaliças", "verduras e hortaliças de cor laranja", "carne, ovos e legumes" e "gordura sólida, álcool e açúcar". Por outro lado, entre adolescentes masculinos, houve uma queda apenas no consumo de "cereais integrais" ( 0,2 vs. 0,1 ; $p=0$,04). Entre 2003 e 2008, a qualidade da dieta de adolescentes femininas deteriorou em Niterói.

Inquéritos sobre Dietas; Consumo de Alimentos; Adolescente
37. Lazarou VE, Dussin DS, Farhat CP, Navarro F. Subnotificação do consumo alimentar de adolescentes. RBONE - Revista Brasileira de Obesidade, Nutrição e Emagrecimento 2007; 1:35-49.

38. Gibson R. Reproducibility in dietary assessment. In: Gibson R, editor. The principles of nutritional assessment. 2nd Ed. Oxford: Oxford University Press; 2005. p. 129-48.

39. Lwanga SK, Lemeshow S. Sample size determination in health studies: a practical manual. Geneva: World Health Organization; 1991.

40. Kac G, Velásquez-Meléndez G. A transição nutricional e a epidemiologia da obesidade na América Latina. Cad Saúde Pública 2003;19 Suppl 1:S4-5.

41. Popkin BM. The nutrition transition and obesity in the developing world. J Nutr 2001; 131:871S-3S.

42. Castro MA, Barros RR, Bueno MB, César CLG, Fisberg RM. Trans fatty acid intake among the population of the city of São Paulo, Brazil. Rev Saúde Pública 2009; 43:991-7.

\section{Resumen}

El estudio tuvo como objetivo analizar los cambios en la calidad de la dieta de adolescentes matriculados en escuelas públicas en Niterói, Estado de Río de Janeiro, Brasil, a lo largo de cinco años. Los datos sobre consumo alimentario de los adolescentes (12-19 años de edad) fueron obtenidos a través de dos conjuntos de registros alimentarios de tres días, en dos estudios transversales de base escolar, en 2003 y 2008. El Índice Brasileño de Alimentación Saludable (IAS-R), versión revisada, se utilizó para estimar la calidad de la dieta. Entre 2003 y 2008, hubo una caída general en la puntuación atribuida al "total de verduras y hortalizas", "verduras y hortalizas de color naranja" y "carne, huevos y legumbres", pero hubo un aumento en el consumo de "leche y lácteos" ( 4,0 vs. 5,2; $p<0,01$ ). Entre adolescentes femeninas hubo una caída del IAS-R (64, 1 vs. 62,$4 ; p=0,04)$, así como, del consumo de "total de verduras y hortalizas", "verduras y hortalizas de color naranja", "carne, huevos y legumbres" y "grasa sólida, alcohol y azúcar". Por otro lado, entre adolescentes masculinos, hubo una caída sólo en el consumo de "cereales integrales" (0,2 vs. 0,1; $p=0,04)$. Entre 2003 y 2008, la calidad de la dieta de adolescentes femeninas se deterioró en Niterói.

Encuestas sobre Dietas; Consumo de Alimentos; Adolescente
Submitted on 04/Aug/2015

Final version resubmitted on 12/Feb/2016

Approved on 02/Mar/2016 